\title{
Volume and energy folding landscape of prion protein revealed by pressure
}

Y. Cordeiro ${ }^{1}$,

J. Kraineva ${ }^{2}$,

R. Winter ${ }^{2}$ and

J.L. Silva ${ }^{1}$
${ }^{1}$ Instituto de Bioquímica Médica, Centro Nacional de Ressonância Magnética Nuclear de Macromoléculas, Universidade Federal do Rio de Janeiro, Rio de Janeiro, RJ, Brasil ${ }^{2}$ Department of Chemistry, Physical Chemistry I, University of Dortmund, Dortmund, Germany

\section{Correspondence}

J.L. Silva

Instituto de Bioquímica Médica

Centro Nacional de Ressonância

Magnética Nuclear de

Macromoléculas

Jiri Jonas, CCS, UFRJ

Bloco E, Sala 10

21941-590 Rio de Janeiro, RJ

Brasil

Fax: +55-21-3881-4155

E-mail: jerson@bioqmed.ufrj.br

Presented at the $3 r d$ International

Conference on High Pressure

Bioscience and Biotechnology,

Rio de Janeiro, RJ, Brazil,

September 27-30, 2004.

Research supported by CNPq, FINEP, FAPERJ, and CAPES to J.L. Silva, International Centre for Genetic Engineering and Biotechnology to J.L. Silva, and DFG to R. Winter.

....................

Received April 26, 2005 Accepted May 30, 2005

\begin{abstract}
The main hypothesis for prion diseases proposes that the cellular protein $\left(\mathrm{PrP}^{\mathrm{C}}\right)$ can be altered into a misfolded, $ß$-sheet-rich isoform, the $\mathrm{PrPSc}^{\mathrm{Sc}}$ (from scrapie). The formation of this abnormal isoform then triggers the transmissible spongiform encephalopathies. Here, we discuss the use of high pressure as a tool to investigate this structural transition and to populate possible intermediates in the folding/unfolding pathway of the prion protein. The latest findings on the application of high pressure to the cellular prion protein and to the scrapie PrP forms will be summarized in this review, which focuses on the energetic and volumetric properties of prion folding and conversion.
\end{abstract}

Key words

- Prion

- High pressure

- Structural conversion

- Aggregation

\section{Introduction}

Since its discovery by Stanley Prusiner in 1982, the prion protein $(\mathrm{PrP})$ has received much attention in the field of medical science (1). This protein is implicated in the neurodegenerative diseases called transmissible spongiform encephalopathies and thus far is believed to be the major agent (or only agent) that causes these affections (2). The onset of a transmissible spongiform encephalopathy is triggered by the conversion of an $\alpha$-helical isoform, which is the cellular PrP, denoted $\mathrm{PrP}^{\mathrm{C}}$, into a $\beta$-sheet-rich form, the prion scrapie, denoted PrPSc or PrP-res (from protease-resistant) (2-5). The $\operatorname{PrP}^{\mathrm{C}}$ is found anchored to the cell membrane mainly in cells of the central nervous system by a glycosylphosphatidylinositol bridge and is rich in $\alpha$-helical structure and highly soluble (6). In contrast, $\mathrm{PrP}^{\mathrm{Sc}}$ is mostly insoluble, presents partial resistance to proteolysis and has a greater $B$-sheet content than $\operatorname{PrP}^{\mathrm{C}}(6,7)$. Although $\mathrm{PrP}^{\mathrm{Sc}}$ may exist in variable truncated forms in vivo, due to its partial resistance to proteolysis (8), both forms are generally derived from the same primary sequence of the prion protein.

The mechanism of conversion from $\mathrm{PrP}^{\mathrm{C}}$ to $\mathrm{PrP}^{\mathrm{Sc}}$ is still under study, and although most research groups suggest that only the presence of the scrapie form is necessary to induce $\mathrm{PrP}^{\mathrm{C}}$ to acquire the misfolded conformation, some researchers have shown that other macromolecular candidate accessory factors, such as heparan sulfate (9-12), proteins $(13,14)$ and nucleic acids $(15-19)$, may be involved in this conversion.

In the last two decades, several groups have published studies on the thermodynamic and structural properties of this unusual protein (20-27). These investigators have described common peculiar solution conditions that favor in vitro formation of 
the polymerized, B-rich and proteinase $\mathrm{K}$ resistant PrP structure, which involve incubation of recombinant PrP under acidic conditions (pH 4 to 6 ) and at denaturing or subdenaturing concentrations of urea or guanidinium salt.

Another approach to the understanding of prion conversion is the use of physical variables - heat, cold and high pressure - to assess the energetic and volumetric values involved in conformation changes (28-32). Another goal of the knowledge of such variables was to reduce or even to abolish infectivity of brain samples containing prion scrapie using these combined treatments, by high temperature autoclaving $(33,34)$.

An important relatively new tool for investigating the conformational transitions of PrP is high pressure, which has an advantage over other methods because its perturbation of macromolecules in solution depends solely on the volume change of the process under study (35). High pressure favors the formation of structures with smaller volumes, and the application of pressure generally hydrates the hydrophobic interior of proteins $(35,36)$. Therefore, proteins with a large volume fraction of solvent-excluded cavities are highly sensitive to pressure $(35,37,38)$, a fact that makes this variable unique for exploring hydration, packing and volumetric properties of proteins. Moreover, pressurization of a particular protein may allow one to populate intermediate species in the folding pathway and to study these conformations, which otherwise would be difficult to isolate by other approaches (39). Since the 1980 's, high pressure has been used successfully to explore protein folding (40), assembly (41), dynamics (42), and structure (43). More recently, high pressure has also been applied to misfolded proteins that form aggregates and amyloids $(32,38,44-46)$.

In this review we will focus on the use of high pressure to dissect in more detail the prion conversion from the $\alpha$-helical to the $\beta$ sheet-rich isoform and folding/unfolding of this protein, which presents one of the major challenges in the neuroscience, biochemical and biophysical fields.

\section{Use of high pressure to abolish prion infectivity}

Although high temperature autoclaving has been used in the last decade to try to reduce or abolish prion infectivity from infected brain-tissue $(33,34)$, high pressure has only been applied for this purpose a few years ago. At first inspection, the application of pressure to infected material seems to be promising, but it only produces significant results when combined with very high temperature $(47,48)$. When several pulses of pressures - pressure pulse technology - above $\sim 700 \mathrm{MPa}$ were applied to the $263 \mathrm{~K}$ scrapie strain adapted to hamsters, a high reduction of infectivity levels was obtained, but always coupled with high temperature incubation of the material (47). A similar result was obtained recently with the same prion strain $(48,49)$. Crude brain homogenates of terminally diseased hamsters infected with the $263 \mathrm{~K}$ scrapie strain were treated at $60^{\circ} \mathrm{C}$ with pressures above $500 \mathrm{MPa}$ (48) or at 800 MPa (49), and the titers of prion infectivity were significantly reduced when treated samples were inoculated into healthy hamsters. Interestingly, when this group applied high pressure $(800 \mathrm{MPa})$ at $60^{\circ} \mathrm{C}$ to purified prion fibrils, resistance to proteinase $\mathrm{K}$ digestion and infectivity were retained, suggesting the existence of distinct $\beta$-structures in the PrP, sensitive or highly resistant to pressure (49). Besides, even for the assays in which prion titers were significantly reduced, abolition of total prion infectivity could not be achieved in any reported study.

\section{Use of high pressure to search for alternative prion conformations}

Several studies have been performed on the thermodynamics and stability of the PrP, 
describing interesting features of this protein (21,50-52). Thus, the main characteristics of the PrP behavior can be clearly determined, but normally the results are quite variable and it is important to carefully analyze the type of prion construction studied in conjunction with the unfolding treatment utilized (see summary of the data in Table 1).

Application of pressure to proteins can reveal different conformations during the unfolding transition, which cannot be obtained by other methods. Soluble native Syrian hamster PrP (ShaPrP ${ }^{90-231}$ ) could be rescued by pressure (200 $\mathrm{MPa}$ and returning to atmospheric pressure, at $70^{\circ} \mathrm{C}$ ) from temperature-induced $ß$-sheet-rich aggregates (45). Interestingly, when pressure was raised over $400 \mathrm{MPa}$ at $40^{\circ} \mathrm{C}$, a conformational interme-

Table 1. Overview of prion isoforms characterized by high pressure.

\begin{tabular}{|c|c|c|c|c|c|}
\hline $\begin{array}{l}\text { Pressure/ } \\
\text { temperature }\end{array}$ & $\begin{array}{l}\text { Prion } \\
\text { construct }\end{array}$ & $\mathrm{pH}$ conditions & $\begin{array}{l}\text { Initial and final } \\
\text { structural properties }\end{array}$ & $\begin{array}{l}\text { Thermodynamic } \\
\text { properties }\end{array}$ & Ref. \\
\hline $\begin{array}{l}3 \text { to } 200 \mathrm{MPa} \\
30^{\circ} \mathrm{C} \text { to }-20^{\circ} \mathrm{C}\end{array}$ & $\begin{array}{l}\text { Native, soluble } \\
\text { SharPrP90-231 }\end{array}$ & $\mathrm{pH} 5.2$ & $\begin{array}{l}\text { Cold denaturation } \\
\text { of ShaPrP achieved }\end{array}$ & $\begin{array}{l}\Delta \mathrm{G}^{0} \text { values were } \\
\text { calculated for individual } \\
\text { residues and ranged } \\
\text { from } 3.0 \text { to } 5.3 \mathrm{kcal} / \mathrm{mol}\end{array}$ & 29 \\
\hline $\begin{array}{l}1 \text { to } 350 \mathrm{MPa} \\
25^{\circ} \mathrm{C}\end{array}$ & $m r P^{121-231}$ & $\begin{array}{l}\mathrm{pH} 7.0 \\
4 \mathrm{M} \text { urea }\end{array}$ & $\begin{array}{l}\text { No complete unfolding } \\
\text { achieved; stabilization } \\
\text { of a partially folded } \\
\text { intermediate }\end{array}$ & $\begin{array}{c}\Delta V=-39 \mathrm{ml} \mathrm{mol}^{-1} \\
\mathrm{a}_{\Delta \mathrm{G}_{\mathrm{int}}}=2.2 \mathrm{kcal} \mathrm{mol}^{-1}\end{array}$ & 59 \\
\hline $\begin{array}{l}350 \mathrm{MPa} \\
25^{\circ} \mathrm{C} \text { to }-9^{\circ} \mathrm{C}\end{array}$ & $m r P r P^{121-231}$ & $\begin{array}{l}\mathrm{pH} 7.0 \\
4 \mathrm{M} \text { Urea }\end{array}$ & $\begin{array}{l}\text { Cold denaturation } \\
\text { achieved under } \\
\text { pressure with } 4 \mathrm{M} \text { urea }\end{array}$ & ${ }^{\mathrm{b}} \Delta \mathrm{G}_{\mathrm{U}}=1.1 \mathrm{kcal} \mathrm{mol}^{-1}$ & 59 \\
\hline $\begin{array}{l}50 \text { to } 275 \mathrm{MPa} \\
70^{\circ} \mathrm{C}\end{array}$ & $\begin{array}{l}\text { Temperature- } \\
\text { induced aggregates } \\
\text { of SharPrP90-231 }\end{array}$ & $\mathrm{pH} 7.0$ & $\begin{array}{l}\text { Pressurization allowed } \\
\text { recovery of native, } \\
\text { non-aggregated ShaPrP }\end{array}$ & Not calculated & 45 \\
\hline $\begin{array}{l}50 \text { to } 600 \mathrm{MPa} \\
40^{\circ} \mathrm{C}\end{array}$ & $\begin{array}{l}\text { Native, soluble } \\
\text { SharPrP90-231 }\end{array}$ & $\mathrm{pH} 7.0$ & $\begin{array}{l}\text { Pressure-induced } \\
\text { unfolding obtained }\end{array}$ & $\begin{aligned} \Delta G_{U} & =3.93 \mathrm{~kJ} \mathrm{~mol}^{-1} \\
\Delta V_{U} & =-31.9 \mathrm{ml} \mathrm{mol}^{-1}\end{aligned}$ & 45 \\
\hline $\begin{array}{l}1 \text { to } 1000 \mathrm{MPa} \\
25^{\circ} \mathrm{C}\end{array}$ & $\begin{array}{l}\text { Native, } \alpha \text {-helical } \\
\text { mrPrP23-231 }\end{array}$ & $\mathrm{pH} 7.5$ & $\begin{array}{l}\text { Pressure-induced } \\
\text { unfolding achieved }\end{array}$ & $\begin{array}{c}\Delta G_{U}^{0}=5.4 \mathrm{kcal} \mathrm{mol}^{-1} \\
\Delta V=-29.2 \mathrm{ml} \mathrm{mol}^{-1} \\
\mathrm{p}_{1 / 2}=540 \mathrm{MPa}\end{array}$ & 30 \\
\hline $\begin{array}{l}1 \text { to } 1100 \mathrm{MPa} \\
25^{\circ} \mathrm{C}\end{array}$ & $\begin{array}{l}\text { Aggregated, } \\
\text { B-sheet-rich } \\
\text { mrPrP23-231 }\end{array}$ & $\mathrm{pH} 7.5$ & $\begin{array}{l}\text { Pressure-induced } \\
\text { unfolding achieved }\end{array}$ & $\begin{array}{c}\Delta G_{U}^{0}=2.8 \mathrm{kcal} \mathrm{mol}^{-1} \\
\Delta V=-43.6 \mathrm{ml} \mathrm{mol}^{-1} \\
\mathrm{p}_{1 / 2}=280 \mathrm{MPa}\end{array}$ & 30 \\
\hline $\begin{array}{l}1 \text { to } 600 \mathrm{MPa} \\
40^{\circ} \mathrm{C}\end{array}$ & SharPrP90-231 & $\mathrm{pH} 8.5$ & $\begin{array}{l}\text { rPrP aggregates } \\
\text { above } 450 \mathrm{MPa}\end{array}$ & Not calculated & 32 \\
\hline $\begin{array}{l}\text { Transient } \\
\text { treatment at } \\
600 \mathrm{MPa}, 40^{\circ} \mathrm{C}\end{array}$ & SharPrP90-231 & $\mathrm{pH} 8.5$ & $\begin{array}{l}\text { Formation of } \\
\text { amorphous aggregates } \\
\text { after pressure release }\end{array}$ & Not calculated & 32 \\
\hline $\begin{array}{l}\text { Overnight } \\
\text { incubation at } \\
600 \mathrm{MPa}, 40^{\circ} \mathrm{C}\end{array}$ & SharPrP90-231 & $\mathrm{pH} 8.5$ & $\begin{array}{c}\text { Formation of amyloid } \\
\text { aggregates after pressure } \\
\text { release }\end{array}$ & Not calculated & 32 \\
\hline
\end{tabular}

aFree energy change corresponding to the transition from the rPrP state at $4 \mathrm{M}$ urea, atmospheric pressure to the partially folded pressure-denatured state. ${ }^{b}$ Free energy change of the transition from the pressuredenatured intermediate state to the fully unfolded state. $p_{1 / 2}=$ pressure value corresponding to $50 \%$ of the transition; SharPrP = Syrian hamster recombinant prion protein; $\mathrm{mrPrP}=$ murine recombinant $\mathrm{PrP}$. 
diate was populated, revealing other advantages for the use of this approach.

Kuwata and co-workers (29) have taken advantage of high-pressure nuclear magnetic resonance to monitor in real time the effect of pressure on the three-dimensional recombinant ShaPrP ${ }^{90-231}$ structure. They could only reach the rPrP denatured state by cooling the sample to $-20^{\circ} \mathrm{C}$ at $200 \mathrm{MPa}$, but at $30^{\circ} \mathrm{C}$ and $200 \mathrm{MPa}$ a locally disordered rPrP intermediate was revealed (29) and more information was published recently (31). The yeast PrP Ure 2 also underwent cold denaturation induced by pressure (200 MPa) (28).

Figure 1. $\alpha$-rPrP and B-rPrP display different stabilities against pressure. The transition values as a function of pressure were obtained from the native $\alpha-r P r P$ $\alpha$-helical secondary structure and from $B$-sheet changes for $B$ rPrP (obtained from Ref. 30). The extent of denaturation $(f)$ was calculated as follows: $f=$ $\left(I R_{\text {obs }}-I R_{\text {initial }} / I R_{\text {final }}-I R_{\text {initial }}\right)$, where $I_{R_{o b s}}$ is the observed IR intensity value at pressure $p$, $I R_{\text {initial }}$ is the IR value at 0.1 $\mathrm{MPa}$, and $I R_{\text {final }}$ is the final IR intensity value of the pressureinduced unfolding curve (from Ref. 30).

Figure 2. Volume (A) and Gibbs free-energy $(B)$ diagrams of $\alpha$ rPrP and B-rPrP. $\alpha$-rPrP (circle) and B-rPrP (triangle) pressuredenatured states are denoted $U$ and $U$ ', respectively. The numbers indicate volume $(\mathrm{ml} / \mathrm{mol})$ (A) and Gibbs free-energy of unfolding $(\mathrm{kcal} / \mathrm{mol})(B)$ determined for $\alpha$-rPrP and B-rPrP pressureinduced unfolding (from Ref. 30).
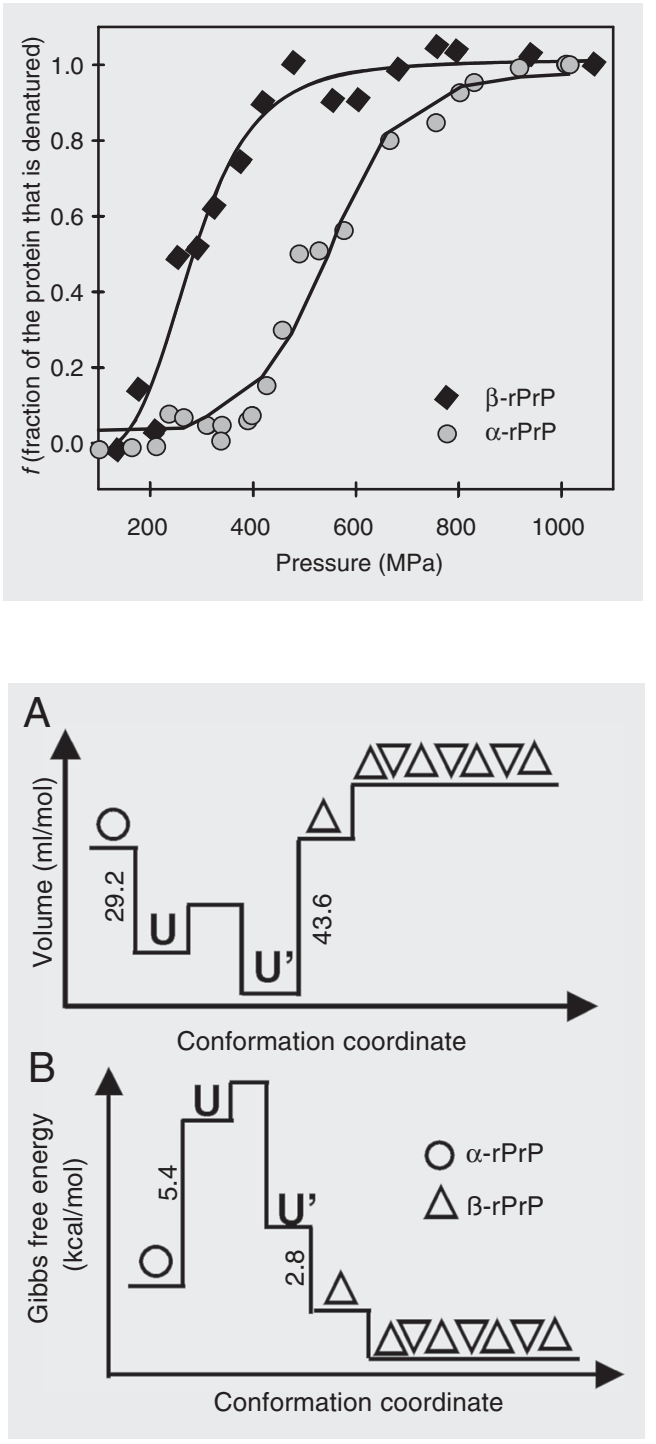

We have also used high pressure to try to reach the rPrP unfolded state. Recently, we confirmed that pressures above $500 \mathrm{MPa}$ promoted denaturation of recombinant mouse PrP ( $\left.\mathrm{rrP}^{23-231}\right)$ (30). The effects of high pressure on $\beta$-sheet-rich $\mathrm{rPrP}$ aggregates $(\beta$ rPrP), which were obtained by thermal treatment, were also investigated (30). The use of high-pressure Fourier-transform infrared spectroscopy (53-56) allowed us to probe the secondary structure of the protein during pressurization. We found that, whereas $\alpha$ helical rPrP undergoes aggregation at high temperature into a $B$-sheet-rich structure, it is markedly resistant to pressure, displaying almost no change in secondary structure up to $400 \mathrm{MPa}$, as reported previously (29). However, the $\beta$-rPrP aggregates were highly susceptible to pressure and dissociated at pressures below $400 \mathrm{MPa}$ (Figure 1). We showed for the first time denaturation of recombinant full-length PrP by high pressure without the use of temperature or denaturants and also reported that newly formed aggregates are less hydrated and have more cavities than native PrP and late aggregates. We calculated the thermodynamic parameters of the $\alpha$-rPrP and $\beta$-rPrP denaturation processes (Figure 2) and observed that the transitions lead to different denatured states (U and U'), which appear to arise from different folding routes: $\alpha$-rPrP denatures into $\mathrm{U}$ with smaller changes in volume whereas B-rPrP denatures into U' with a larger volume change. There is a clear kinetic barrier, both in the volume (activation volume) and in the Gibbs free energy (activation energy) between U and U' (Figure 2). This unusual property is probably related to both the slow in vivo conversion and to the infectious nature of prion diseases. It may also explain the inability to show that any $B$-sheet-rich form obtained from recombinant PrP is an efficient infectious agent. Nevertheless, in vitro ß-sheet isoforms have physical properties similar to $\mathrm{PrP}^{\mathrm{Sc}}$, and amyloid-like aggregates exhibit epitopes equivalent to those of 
scrapie $\operatorname{PrP}$ (26). Indeed, it is quite intriguing why infectious $\mathrm{PrP}^{\mathrm{Sc}}$ cannot be refolded in vitro, without a $\mathrm{PrP}^{\mathrm{Sc}}$ template, as demonstrated by Kocisko et al. (57).

The greater pressure stability of $\alpha-r P r P$, as determined by its higher standard Gibbs free energy change of unfolding $\left(\Delta \mathrm{G}^{0}=5.37\right.$ $\pm 0.15 \mathrm{kcal} / \mathrm{mol}$ ) in contrast to that of $\beta-\mathrm{rPrP}$ $\left(\Delta \mathrm{G}^{0}=2.81 \pm 0.10 \mathrm{kcal} / \mathrm{mol}\right)$, seems paradoxical at first glance since the chemical potential of these two forms shows the opposite. For the free-energy diagram, we assumed a metastability model for the conversion of $\alpha$-rPrP into $\beta$-rPrP (25). The apparent contradiction is resolved by the finding that their $\mathrm{N} \leftrightarrow \mathrm{U}$ transitions are not connected at equilibrium, and by the fact that $\alpha$ rPrP is converted into $\beta$-rPrP by increasing the temperature and no further unfolding is caused by temperatures as high as $95^{\circ} \mathrm{C}$. The volume and free-energy diagrams revealed by pressure agree with recent thermodynamic and kinetic data showing that partially structured intermediates are essential in the folding pathway $(52,58,59)$.

Another interesting finding was that pressure could distinguish between early and late prion aggregates obtained by incubation at high temperatures for short or long time. The rPrP aggregate obtained by incubation at $50^{\circ} \mathrm{C}$ for 2 days was completely pressure resistant, in contrast with the aggregate incubated for $2 \mathrm{~h}$ at the same temperature. This was rather surprising because, generally, oligomeric proteins $(37,60)$ and amyloid aggregates $(38,44)$ dissociate in the pressure range from 100 to $300 \mathrm{MPa}$. And, according to the principle of Le Châtelier, pressure shifts the equilibrium to conformational states that occupy smaller volumes $(37,60)$, nor- mally leading to dissociation of oligomeric proteins (35) or to protein unfolding (60). However, since this mature aggregate did not unfold up to $1,200 \mathrm{MPa}$, we assumed that it no longer contained internal cavities susceptible to pressurization, and hence could be considered rather densely packed.

Another interesting application of pressure in the PrP studies is to try to obtain PrP aggregates, which could be used as models for the prion scrapie. The rPrP from hamster was converted to a novel misfolded conformer that aggregated in amyloid fibrils by overnight incubation at $600 \mathrm{MPa}, 40^{\circ} \mathrm{C} \mathrm{(32)}$. And these pressure-induced aggregates were also resistant to proteinase $\mathrm{K}$.

In conclusion, we believe that high pressure is a valuable tool for investigating prion transition even without the concomitant use of temperature or chemical denaturants, and recombinant prion aggregates display different susceptibilities to high pressure depending on time of exposure to high temperature during aggregation. We show that different folded conformations as well as different denatured states of rPrP can be distinguished on the basis of hydration, surface exposure and cavities. These dissimilarities result in the paradox that $\beta-\mathrm{rPrP}$ is highly resistant to temperature whereas it is very sensitive to pressure; the opposite occurs with the native $\alpha-r P r P$.

\section{Acknowledgments}

We thank Prof. Luís Maurício T.R. Lima for critical reading the manuscript and precious suggestions and Emerson R. Gonçalves for excellent technical support.

\section{References}

1. Prusiner SB (1982). Novel proteinaceous infectious particles cause scrapie. Science, 216: 136-144.

2. Prusiner SB (1998). Prions. Proceedings of the National Academy of Sciences, USA, 95: 13363-13383.
3. Weissmann C (1999). Molecular genetics of transmissible spongiform encephalopathies. Journal of Biological Chemistry, 274: 3-6.

4. Caughey B (2001). Interactions between prion protein isoforms: the kiss of death? Trends in Biochemical Sciences, 26: 235-242. 
5. Aguzzi A \& Polymenidou M (2004). Mammalian prion biology: one century of evolving concepts. Cell, 116: 313-327.

6. Pan KM, Baldwin M, Nguyen J et al. (1993). Conversion of alphahelices into beta-sheets features in the formation of the scrapie prion proteins. Proceedings of the National Academy of Sciences, USA, 90: 10962-10966.

7. Caughey BW, Dong A, Bhat KS et al. (1991). Secondary structure analysis of the scrapie-associated protein PrP27-30 in water by infrared spectroscopy. Biochemistry, 30: 7672-7680.

8. Caughey B, Raymond GJ, Ernst D et al. (1991). N-terminal truncation of the scrapie-associated form of PrP by lysosomal protease(s): implications regarding the site of conversion of $\operatorname{PrP}$ to the proteaseresistant state. Journal of Virology, 65: 6597-6603.

9. Snow AD, Wight TN, Nochlin D et al. (1990). Immunolocalization of heparan sulfate proteoglycans to the prion protein amyloid plaques of Gerstmann-Sträussler syndrome, Creutzfeldt-Jakob disease and scrapie. Laboratory Investigation, 63: 601-611.

10. Caughey B \& Raymond GJ (1993). Sulfated polyanion inhibition of scrapie-associated PrP accumulation in cultured cells. Journal of Virology, 67: 643-650.

11. Gabizon R, Meiner Z, Halimi M et al. (1993). Heparin-like molecules bind differentially to prion-proteins and change their intracellular metabolic fate. Journal of Cell Physiology, 157: 319-325.

12. Wong C, Xiong L-W, Horiuchi M et al. (2001). Sulfated glycans and elevated temperature stimulate PrPSc-dependent cell-free formation of protease-resistant prion protein. EMBO Journal, 20: 377-386.

13. Telling GC, Scott M, Mastrianni J et al. (1995). Prion propagation in mice expressing human and chimeric PrP transgenes implicates the interaction of cellular PrP with another protein. Cell, 83: 79-90.

14. Kaneko K, Zulianello L, Scott M et al. (1997). Evidence for protein X binding to a discontinuous epitope on the cellular prion protein during scrapie prion propagation. Proceedings of the National Academy of Sciences, USA, 94: 10069-10074.

15. Cordeiro Y, Machado F, Juliano L et al. (2001). DNA converts cellular prion protein into the beta-sheet conformation and inhibits prion peptide aggregation. Journal of Biological Chemistry, 276: 49400-49409.

16. Deleault NR, Lucassen RW \& Supattapone S (2003). RNA molecules stimulate prion protein conversion. Nature, 425: 717-720.

17. Caughey B \& Kocisko DA (2003). Prion diseases: a nucleic-acid accomplice? Nature, 425: 673-674.

18. Cordeiro Y, Lima LMTR, Gomes MP et al. (2004). Modulation of prion protein oligomerization, aggregation, and beta-sheet conversion by 4,4'-dianilino-1,1'-binaphthyl-5,5'-sulfonate (bis-ANS). Journal of Biological Chemistry, 279: 5346-5352.

19. Nandi PK \& Nicole JC (2004). Nucleic acid and prion protein interaction produces spherical amyloids which can function in vivo as coats of spongiform encephalopathy agent. Journal of Molecular Biology, 344: 827-837.

20. Safar J, Roller PP, Gajdusek DC et al. (1993). Thermal stability and conformational transitions of scrapie amyloid (prion) protein correlate with infectivity. Protein Science, 2: 2206-2216.

21. Swietnicki W, Petersen R, Gambetti P et al. (1997). pH-dependent stability and conformation of the recombinant human prion protein PrP(90-231). Journal of Biological Chemistry, 272: 27517-27520.

22. Riek R, Wider G, Billeter M et al. (1998). Prion protein NMR structure and familial human spongiform encephalopathies. Proceedings of the National Academy of Sciences, USA, 95: 11667-11672.

23. Cohen FE (1999). Protein misfolding and prion diseases. Journal of Molecular Biology, 293: 313-320.

24. Swietnicki W, Morillas M, Chen SG et al. (2000). Aggregation and fibrillization of the recombinant human prion protein huPrP90-231. Biochemistry, 39: 424-431.

25. Baskakov IV, Legname G, Prusiner SB et al. (2001). Folding of prion protein to its native alpha-helical conformation is under kinetic control. Journal of Biological Chemistry, 276: 19687-19690.

26. Baskakov IV, Legname G, Baldwin MA et al. (2002). Pathway complexity of prion protein assembly into amyloid. Journal of Biological Chemistry, 277: 21140-21148.

27. Baskakov IV, Legname G, Gryczynski Z et al. (2004). The peculiar nature of unfolding of the human prion protein. Protein Science, 13: 586-595.

28. Zhou JM, Zhu L, Balny $C$ et al. (2001). Pressure denaturation of the yeast prion protein Ure2. Biochemical and Biophysical Research Communications, 287: 147-152.

29. Kuwata K, Li H, Yamada H et al. (2002). Locally disordered conformer of the hamster prion protein: a crucial intermediate to PrPSc? Biochemistry, 41: 12277-12283.

30. Cordeiro Y, Kraineva J, Ravindra R et al. (2004). Hydration and packing effects on prion folding and beta-sheet conversion. High pressure spectroscopy and pressure perturbation calorimetry studies. Journal of Biological Chemistry, 279: 32354-32359.

31. Kuwata K, Kamatari YO, Akasaka K et al. (2004). Slow conformational dynamics in the hamster prion protein. Biochemistry, 43: 4439-4446.

32. Torrent J, Alvarez-Martinez MT, Harricane MC et al. (2004). High pressure induces scrapie-like prion protein misfolding and amyloid fibril formation. Biochemistry, 43: 7162-7170.

33. Taylor DM \& Fernie K (1996). Exposure to autoclaving or sodium hydroxide extends the dose-response curve of the $263 \mathrm{~K}$ strain of scrapie agent in hamsters. Journal of General Virology, 77: 811813.

34. Schreuder BE, Geertsma RE, van Keulen LJ et al. (1998). Studies on the efficacy of hyperbaric rendering procedures in inactivating bovine spongiform encephalopathy (BSE) and scrapie agents. Veterinary Research, 142: 474-480.

35. Silva JL, Foguel D \& Royer C (2001). Pressure provides new insights into protein folding, dynamics and structure. Trends in Biochemical Sciences, 26: 612-618.

36. Royer CA (2002). Revisiting volume changes in pressure-induced protein unfolding. Biochimica et Biophysica Acta, 25: 201-209.

37. Mozhaev VV, Heremans K, Frank J et al. (1996). High pressure effects on protein structure and function. Proteins, 24: 81-91.

38. Foguel D, Suarez MC, Ferrão-Gonzales AD et al. (2003). Dissociation of amyloid fibrils of alpha-synuclein and transthyretin by pressure reveals their reversible nature and the formation of waterexcluded cavities. Proceedings of the National Academy of Sciences, USA, 100: 9831-9836.

39. Foguel D \& Silva JL (2004). New insights into the mechanisms of protein misfolding and aggregation in amyloidogenic diseases derived from pressure studies. Biochemistry, 43: 11361-11370.

40. Weber G \& Drickamer HG (1983). The effect of high pressure upon proteins and other biomolecules. Quarterly Reviews of Biophysics, 16: 89-112.

41. Silva JL, Foguel D, Suarez M et al. (2004). High-pressure applications in medicine and pharmacology. Journal of Physics: Condensed Matter, 16: S929-S944.

42. Jonas J \& Jonas A (1994). High-pressure NMR spectroscopy of proteins and membranes. Annual Review of Biophysics and Biomolecular Structure, 23: 287-318.

43. Akasaka K, Tezuka T \& Yamada H (1997). Pressure-induced changes in the folded structure of lysozyme. Journal of Molecular 
Biology, 271: 671-678.

44. Ferrão-Gonzales AD, Souto SO, Silva JL et al. (2000). The preaggregated state of an amyloidogenic protein: hydrostatic pressure converts native transthyretin into the amyloidogenic state. Proceedings of the National Academy of Sciences, USA, 97: 64456450.

45. Torrent J, Alvarez-Martinez MT, Heitz F et al. (2003). Alternative prion structural changes revealed by high pressure. Biochemistry, 42: 1318-1325.

46. Ishimaru D, Andrade LR, Teixeira LS et al. (2003). Fibrillar aggregates of the tumor suppressor p53 core domain. Biochemistry, 42: 9022-9027.

47. Brown P, Meyer R, Cardone F et al. (2003). Ultra-high-pressure inactivation of prion infectivity in processed meat: a practical method to prevent human infection. Proceedings of the National Academy of Sciences, USA, 100: 6093-6097.

48. Fernandez-Garcia A, Heindl P, Voigt $\mathrm{H}$ et al. (2004). Reduced proteinase $\mathrm{K}$ resistance and infectivity of prions after pressure treatment at 60 degrees C. Journal of General Virology, 85: 261-264.

49. Garcia AF, Heindl $P$, Voigt $H$ et al. (2005). Dual nature of the infectious prion protein revealed by high pressure. Journal of Biological Chemistry, 280: 9842-9847.

50. Perrett S, Freeman SJ, Butler PJ et al. (1999). Equilibrium folding properties of the yeast prion protein determinant Ure2. Journal of Molecular Biology, 290: 331-345.

51. Perrett S \& Zhou JM (2002). Expanding the pressure technique: insights into protein folding from combined use of pressure and chemical denaturants. Biochimica et Biophysica Acta, 1595: 210-
223.

52. Apetri AC \& Surewicz WK (2003). Atypical effect of salts on the thermodynamic stability of human prion protein. Journal of Biological Chemistry, 278: 22187-22192.

53. Byler DM \& Susi H (1986). Examination of the secondary structure of proteins by deconvolved FTIR spectra. Biopolymers, 25: 469-487.

54. Panick G, Malessa R \& Winter R (1999) Differences between the pressure- and temperature-induced denaturation and aggregation of beta-lactoglobulin A, B, and AB monitored by FT-IR spectroscopy and small-angle $X$-ray scattering. Biochemistry, 38: 6512-6519.

55. Dzwolak W, Ravindra R, Lendermann J et al. (2003). Aggregation of bovine insulin probed by DSC/PPC calorimetry and FTIR spectroscopy. Biochemistry, 42: 11347-11355.

56. Herberhold H, Marchal S, Lange R et al. (2003). Characterization of the pressure-induced intermediate and unfolded state of red-shifted green fluorescent protein - a static and kinetic FTIR, UV/VIS and fluorescence spectroscopy study. Journal of Molecular Biology, 330: 1153-1164.

57. Kocisko DA, Come JH, Priola SA et al. (1994). Cell-free formation of protease-resistant prion protein. Nature, 370: 471-474.

58. Apetri AC, Surewicz KA \& Surewicz WK (2004). The effect of disease-associated mutations on the folding pathway of human prion protein. Journal of Biological Chemistry, 279: 18008-18014.

59. Martins SM, Chapeaurouge A \& Ferreira ST (2003). Folding intermediates of the prion protein stabilized by hydrostatic pressure and low temperature. Journal of Biological Chemistry, 278: 50449-50455.

60. Silva JL \& Weber G (1993). Pressure stability of proteins. Annual Review of Physical Chemistry, 44: 89-113. 